\title{
COVID-19 Vaccine in Pregnant and Lactating Women: A Review of Existing Evidence and Practice Guidelines
}

\author{
Ishan Garg $^{1}$, Rahul Shekhar ${ }^{2}\left(\mathbb{D}\right.$, Abu B. Sheikh ${ }^{2} \mathbb{D}$ and Suman Pal ${ }^{2, *} \mathbb{D}$ \\ 1 Mayo Clinic College of Medicine, Mayo Clinic, Rochester, MN 55902, USA; ishangargmd@gmail.com \\ 2 Department of Internal Medicine, University of New Mexico Health Sciences Center, \\ Albuquerque, NM 87106, USA; rshekhar@salud.unm.edu (R.S.); absheikh@salud.unm.edu (A.B.S.) \\ * Correspondence: Spal@salud.unm.edu
}

check for updates

Citation: Garg, I.; Shekhar, R.;

Sheikh, A.B.; Pal, S. COVID-19

Vaccine in Pregnant and Lactating Women: A Review of Existing Evidence and Practice Guidelines. Infect. Dis. Rep. 2021, 13, 685-699. https://doi.org/10.3390/idr13030064

Academic Editor: Nicola Petrosillo

Received: 20 June 2021

Accepted: 28 July 2021

Published: 31 July 2021

Publisher's Note: MDPI stays neutral with regard to jurisdictional claims in published maps and institutional affiliations.

Copyright: (c) 2021 by the authors. Licensee MDPI, Basel, Switzerland. This article is an open access article distributed under the terms and conditions of the Creative Commons Attribution (CC BY) license (https:// creativecommons.org/licenses/by/ $4.0 /)$.

\begin{abstract}
Coronavirus 2019 (COVID-19) has created a global pandemic that is devastating human lives, public healthcare systems, and global economies. Multiple effective and safe COVID-19 vaccines have been developed at an unprecedented speed due to the efforts of the scientific community, and collaboration between the federal government and pharmaceutical companies. However, the continued exclusion of pregnant and lactating women from the COVID anti-viral and vaccine trials has created the paradox of a lack of empirical evidence in a high-risk population. Based on the experience of similar prior vaccines, animal developmental and reproductive toxicology studies, and preliminary findings from human studies, various healthcare professional advisory committees (Advisory Committee on Immunization Practices, American College of Obstetricians and Gynecologists, Society for Maternal-Fetal Medicine, and Academy of Breastfeeding Medicine) have issued guidance supporting COVID-19 vaccination in pregnant and lactating women. In this article, we summarize the available data on the efficacy and safety profile of COVID-19 vaccination in pregnant and lactating women, review the challenges of vaccine hesitancy, and include recommendations for healthcare providers.
\end{abstract}

Keywords: Coronavirus 2019; COVID-19; vaccine; COVID-19 vaccines; pregnancy; lactation; breast feeding; fertility

\section{Introduction}

The coronavirus disease 2019 (COVID-19) pandemic has created a global health crisis of unprecedented proportions. It is caused by the severe acute respiratory syndrome coronavirus 2 (SARS-CoV-2). More than 173 million cases and 3.7 million deaths have been attributed to COVID-19 globally [1]. Along with this devastating loss of human life, the COVID-19 pandemic has also put an extraordinary strain on public healthcare systems and global economies [2]. Vaccination and public health measures, including wearing facemasks, social distancing, and personal hygiene, remain the most promising means of controlling this global pandemic. With this hope, multiple COVID-19 vaccines are being developed, approved, and manufactured for global use while still upholding rigorous regulatory processes [3-5].

It is important to note that pregnant and lactating women were excluded from clinical trials of COVID-19 vaccines, despite being at increased risk of developing severe illness from COVID-19 compared with non-pregnant females [6-15]. Pregnant females with COVID-19 are also at increased risk of hospitalization, intensive-care unit (ICU) admission, invasive ventilation support, and preterm birth compared with pregnant females without COVID-19 [14-16]. Several studies have also shown a small, $2 \%$ to 3\% risk of vertical transmission and the presence of viral RNA in breast milk of mothers infected with COVID19 [17-26].

Millions of women have become pregnant, given birth, and initiated breastfeeding since the start of the COVID-19 pandemic. This has created an ethical and clinical co- 
nundrum on protecting our vulnerable pregnant and lactating population while lacking empirical evidence. Based on limited data, advisory committees from the Centers for Disease Control and Prevention (CDC) and Advisory Committee on Immunization Practices (ACIP), American College of Obstetricians and Gynecologists (ACOG), and the American Academy of Pediatrics (AAP) have issued guidance indicating that COVID-19 vaccines should not be withheld from pregnant persons $[6,27,28]$.

The purpose of this article is to provide an overview of the efficacy and safety of COVID-19 vaccination in pregnant and lactating women, with a review of limited data and theoretical considerations and review-recommended guidelines for clinical use.

\section{COVID-19 Vaccines}

Scientific ingenuity combined with federal government support has led to the development of several vaccine candidates for COVID-19 at a breakneck speed. The US Department of Health and Human Services announced the framework for Operation Warp Speed, a partnership approach between the U.S. Government and the pharmaceutical industry, on 15 May 2020, to accelerate the development of safe, effective COVID-19 vaccines. At present, there are 93 vaccines under clinical trials on humans and at least 77 preclinical vaccines under investigation in animals [29].

Six leading vaccine candidates have received some form of federal government support through Operation Warp Speed. These can be divided into three different types based on their mechanism of action: messenger RNA (mRNA) (BNT162b2 Pfizer BioNTech (Pfizer, Inc., Philadelphia, PA, USA) and mRNA-1273 Moderna vaccines (ModernaTX, Inc., Cambridge, MA, USA)), viral vector (AstraZeneca, Janssen Ad26.COV2.S) (Janssen Biotech, Inc, Johnson \& Johnson, New Brunswick, NJ, USA), and recombinant antigen proteins manufactured in a baculovirus (DNA virus that infects insect cells) system (Novavax (Novavax, Inc., Gaithersburg, MD, USA) and GSK-Sanofi (Sanofi Inc., Bridgewater, NJ, USA; GlaxoSmithKline Inc., Philadelphia, PA, USA).

Moderna was the first one to be granted Emergency Use Authorization (EUA) by the FDA. EUA is an authority provided to the FDA to allow unapproved medical products to be used in a public health emergency to diagnose, treat, or prevent serious or life-threatening conditions when there are no adequate, approved, and available alternatives [30]. However, it is worth noting that the FDA implemented a more rigorous review process to maintain higher standards for COVID-19 vaccine, given that they would be used on a large population [31]. Since then, various other vaccines have been approved. The COVID-19 vaccines that have been approved by WHO under the emergency use listing (EUL) include Pfizer/BioNTech, Moderna, Janssen, AstraZeneca (produced by SK Bio and Serum Institute of India-Covishield), Sinopharm (China National Pharmaceutical Group, Beijing, China), and Sinovac-CoronaVac (Sinovac Biotech Ltd., Beijing, China) vaccines.

\section{1. $m R N A$}

The Pfizer-BioNTech and Moderna vaccines are lipid nanoparticle mRNA vaccines. The vaccine mRNA encodes for the SARS-CoV-2 spike protein, which attaches the virus to angiotensin-converting enzyme 2 (ACE2) to initiate the infection process. The lipid nanoparticles facilitate entry into the cell at the site of injection. The mRNA is then transcribed in the host cell, producing the spike protein, which is subsequently presented on the cell surface to $B$ and T cells, resulting in immune response [32-37].

Both of these FDA-approved mRNA vaccines have shown robust immune response and protection against severe COVID-19 [38,39]. The reported efficacy of Pfizer-BioNTech and Moderna vaccines is $95 \%$ and $94 \%$, respectively, in preventing COVID-19 in participants of phase III clinical trials (16 years and older for Pfizer/BioNtech vaccine and 18 years or older for Moderna vaccine) [38-40]. Common side effects included injection site reactions (84.1\% for the Pfizer/BioNTech vaccine, $91.6 \%$ for the Moderna vaccine), fatigue $(62.9 \%$, $68.5 \%)$, headache $(55.1 \%, 63.0 \%)$, muscle pain $(38.3 \%, 59.6 \%)$, chills $(31.9 \%, 43.4 \%)$, joint pain $(23.6 \%, 44.8 \%)$, and fever $(14.2 \%, 14.8 \%)$, all of which generally resolve within a 
day or two. On rare occasions, mRNA vaccines can trigger myocarditis, anaphylaxis, or Bell's palsy. Therefore, the CDC recommends monitoring vaccine recipients $15 \mathrm{~min}$ after their COVID-19 shot or for $30 \mathrm{~min}$ if they have a history of severe allergies [41-43]. Pfizer-BioNTech vaccine is currently approved for individuals aged 12 years or older, while the Moderna vaccine is approved for 18 years or older. Both vaccines require two doses, 21 (Pfizer-BioNTech, Brooklyn, NY, USA) to 28 days (Moderna, Cambridge, MA, USA) apart [44].

\subsection{Viral Vector}

These vaccines, for example, Oxford-AstraZeneca and Johnson \& Johnson Janssen Ad26.COV2.S vaccines use viral vectors for the delivery of spike protein RNA into the host cell. The viral vector is made from a modified version of a harmless (modified nonreplicating) adenovirus. The final vaccine product contains the spike protein found in SARS-CoV-2 and elicits an immune response via a similar mechanism to mRNA-based vaccines.

Oxford / AstraZeneca vaccine requires two doses, while the Janssen vaccine is authorized for use as a single dose vaccine. At present, only the Janssen vaccine has EUA for use in the U.S for individuals aged 18 years or older. [45].

Common side effects of the Janssen vaccine include injection site pain [48.6\%], headache [38.9\%], fatigue [38.2\%], and myalgia [33.2\%], all of which generally resolve within a day or two. The severity of these symptoms is noted to be considerably less than the mRNAbased vaccines. On rare occasions, Janssen vaccine can cause radiculitis and Guillain-Barre syndrome. Other rare, albeit serious, potentially life-threatening cases of thrombosis with thrombocytopenia syndrome (TTS) have been noted following the Janssen COVID-19 vaccine [46]. Interestingly, all the 15 reported cases (after 7.98 million vaccine doses) have been reported in females. Pregnancy, hormone therapy, or birth control pills are pre-existing risk factors for thrombosis [47]. Therefore, it is advisable to counsel women younger than 50 years old about the increased risk of thrombosis with the Janssen vaccine [48]. The salient features of the Moderna, Pfizer- BioNTech, and Janssen vaccines are summarized in Table 1.

Table 1. COVID vaccines granted an Emergency Use Authorization (EUA) by Federal Drug Administration (FDA) and/or Emergency use listing (EUL) by WHO.

\begin{tabular}{|c|c|c|c|c|c|c|}
\hline & Pfizer/BioNTech & Moderna & Janssen & \multicolumn{2}{|c|}{ Oxford/AstraZenecaSinopharm } & SinoVac \\
\hline Target Population & Age 12 and older & \multicolumn{5}{|c|}{ Age 18 and older } \\
\hline $\begin{array}{c}\text { Vaccine } \\
\text { Administration }\end{array}$ & $\begin{array}{c}2 \text { doses, } 21 \text { days } \\
\text { apart }\end{array}$ & $\begin{array}{c}2 \text { doses, } 28 \text { days } \\
\text { apart }\end{array}$ & 1 dose & $\begin{array}{c}2 \text { doses, } 8 \text { to } 12 \\
\text { weeks apart }\end{array}$ & \multicolumn{2}{|c|}{2 doses, 21 to 28 days apart } \\
\hline Efficacy & $95 \%$ & $94.1 \%$ & $\begin{array}{r}72 \% \text { overall ai } \\
86 \% \text { against } \\
\text { severe diseas }\end{array}$ & $63.1 \%$ & $73 \%$ & $83.5 \%$ \\
\hline \multirow{3}{*}{ Side effects } & \multicolumn{6}{|c|}{ Most common-injection site pain, fatigue, headache, muscle pain, joint pain, \& fever } \\
\hline & \multicolumn{2}{|c|}{ More common after the second dose } & - & \multicolumn{3}{|c|}{ More common after the second dose } \\
\hline & \multicolumn{2}{|c|}{$\begin{array}{l}\text { Rare-Severe allergic reaction Bell's } \\
\text { palsy, myocarditis, \& pericarditis }\end{array}$} & \multicolumn{2}{|c|}{$\begin{array}{l}\text { Rare-TTS, post-vaccination } \\
\text { syndrome, radiculitis, GBS }\end{array}$} & $\mathrm{N} / \mathrm{A}$ & $\mathrm{N} / \mathrm{A}$ \\
\hline \multirow{2}{*}{$\begin{array}{l}\text { Safety in Preg- } \\
\text { nant/Lactating } \\
\text { women }\end{array}$} & \multicolumn{4}{|c|}{ Animal Studies-No safety concerns } & \multicolumn{2}{|c|}{ Animal Studies -N/A } \\
\hline & \multicolumn{6}{|c|}{ Human Studies-N/A } \\
\hline
\end{tabular}

N/A—Not Available, GBS—Guillain-Barre syndrome, TTS—-thrombosis with thrombocytopenia syndrome.

\subsection{Recombinant Antigen Proteins}

These vaccines, for example, Novavax and GSK-Sanofi, use protein subunits combined, mixed with an adjuvant (an adjuvant is an ingredient used to strengthen the immune response). Unlike other vaccines, these vaccines contain the spike protein itself and, when 
injected into the body, illicit an immune response like other vaccines. These vaccines are still in clinical trial phases and have not been approved for use. The reported efficacy of NOVAX is $96.4 \%$ in reducing mild and moderate disease and $100 \%$ against severe disease from the COVID-19 [49].

\subsection{Inactivated COVID-19 Virus}

These vaccines, such as WIV04 and HB02 (Sinopharm, Beijing, China), Coronavac (Sinovac, Beijing, China), use inactivated COVID-19 virus to trigger an immunologic response in the host. Both Sinopharm and Sinovac use aluminum hydroxide as adjuvant. These vaccines do not contain the live virus and therefore cannot cause the disease. The reported efficacy of Sinopharm and Sinovac is 73\% (40,000 participants) and $83.5 \%$ (10,000 participants; preventing COVID-19 in those without prior infection) from the phase III trials, respectively. Both vaccines require two doses. Common side effects included injection site reactions, fatigue, headache, muscle pain, chills, joint pain, and fever, all of which generally resolve within a day or two. These vaccines are available in China and some other countries, including the United Arab Emirates, Brazil, Chile, Indonesia, Mexico, Turkey, and Hungary. At present, these vaccines are not approved for use in the United States.

\section{Clinical Trials of COVID-19 Vaccine in Pregnant and Lactating Women}

Pregnant and lactating women are usually not included in the vaccine research, primarily because of safety and liability concerns, not only for the mother but also the baby [50-54]. However, systemic exclusion of this vulnerable population from clinical trials, including from SARS-CoV-2 vaccine trials, also means limited available data on vaccine safety and efficacy in pregnant and lactating women.

At present, there are over 300 clinical trials exploring new medications and vaccines for COVID-19; however, pregnant women are excluded from all these trials [55]. However, Pfizer (23 pregnancies) and Moderna (12 pregnancies) reported that a few participants inadvertently became pregnant during the trials.

Several efforts have been made over the years to address the exclusion of pregnant women from clinical trials of new medications and vaccines, including [56,57], for example, the National Institute of Allergy and Infectious Diseases has developed guidelines for protocol design and safety assessment for clinical trials conducted in pregnant persons. In 2018, the FDA provided a framework for the inclusion of pregnant persons in clinical trials [58]. The Task Force on Research Specific to Pregnant Women and Lactating Women recommends, "inclusion of pregnant women and lactating women in clinical trials, unless there are compelling scientific reasons for their exclusion [59]." Despite these efforts, very little actual progress has been made as this population continues to be excluded from clinical trials.

In recognition of the importance of the inclusion of pregnant women in COVID-19 vaccine clinical trials, the FDA recommended conducting developmental and reproductive toxicology studies (DART) before enrolling pregnant people or persons who are not actively avoiding pregnancy in clinical trials [60]. The developmental and reproductive toxicology studies are designed to study the effect of new medication or vaccines on the full spectrum of reproduction in animals. mRNA-based Moderna vaccine submitted these results to the FDA on December 4, 2020 [61]. Pfizer has recently announced a global Phase 2/3 trial to evaluate the safety, tolerability, and immunogenicity of the COVID-19 vaccine in pregnant women [62]. The trial is a randomized, placebo-controlled, observer-blind study and will include 4000 healthy women vaccinated between 24 and 34 weeks of gestation [63]. Modera has announced a prospective observational study to assess obstetric, neonatal, and infant outcomes and has created a registry. Johnson \& Johnson subsidiary Janssen is also planning a phase 2 placebo-controlled trial including 824 pregnant females [64].

CDC has also created a voluntary smartphone-based app called "v-safe," which includes pregnant women, to register voluntary reporting of adverse events following 
COVID-19 vaccination. Data collected so far include over 50,000 pregnant women and show no serious vaccine-related adverse events [65]. The United Kingdom has also created a similar registry for its citizens, showing similar results with no safety concerns related to COVID-19 vaccination [66]. The University of Washington has also established a similar registry involving individuals who are pregnant, postpartum, lactating, or contemplating pregnancy in the next 1 or 2 years. Harvard School of Public Health is also working on developing a registry to evaluate obstetric, neonatal, and infant outcomes after COVID-19 vaccination during pregnancy. Modi et al. suggest that regulators should mandate the development of "pregnancy-investigation plans" to describe the development pathway for vaccines and medicines that will be used in pregnancy in an approach similar to the European Medicines Agency's "pediatric investigation plans" for medicines used in children $[67,68]$.

A combination of (i) strong advocacy groups providing regulatory framework and guidelines for inclusion of pregnant and lactating women in COVID-19 vaccine clinical trials, and (ii) leveraging data collected DART studies, accidental pregnancies during clinical trials, and various safety profile registries can help bridge the gap between evidencebased recommendations and expert opinion on COVID-19 vaccination in pregnant and lactation women [69-71].

\section{Impact of COVID-19 Vaccine in Pregnant Women}

Despite potentially devastating consequences of COVID-19 infection in pregnant women and the availability of safe and efficacious (in non-pregnant populations) COVID19 vaccination, there is limited published data describing the safety or efficacy of any COVID-19 vaccine in human pregnancy. Approval of vaccine use intended for pregnant or breastfeeding women rely on a critical review of observational studies, clinical case reports, registries, and clinical trials to ascertain if the vaccine is: (i) safe-no adverse pregnancy outcomes or potential harm to mother and/or fetus, (ii) efficacious-reduce morbidity in the pregnant woman and/or fetus [72-81]. These reviews are conducted through collaborative efforts between the World Health Organization (WHO), CDC, National Institutes of Health (NIH), ACIP, Task Force on Research Specific to Pregnant Women and Lactating Women, and Global Advisory Committee on Vaccine Safety, among others.

Data from Pfizer/BioNTech, Moderna, and Janssen vaccines' animal DART studies have found no safety concerns with no adverse effect on female reproduction, fertility, fetal or embryonal, or postnatal development, miscarriage $[6,11,38,39,82-85]$. Preliminary human studies on mRNA-based vaccines, including the Zika virus, influenza virus, and rabies virus, have shown good safety and immunogenicity profile during pregnancy [86-92].

In a prospective cohort study including 131 reproductive-age vaccine recipients (84 pregnant, 31 lactating, and 16 non-pregnant women), Gray et al. reported that mRNAbased COVID-19 vaccines generated robust humoral immunity in pregnant and lactating women, with immunogenicity and reactogenicity similar to that observed in non-pregnant women. They also reported the transfer of protective immunoglobulins to neonates via placenta and breastmilk [93].

Shimabukuro et al. analyzed data on the safety of mRNA COVID-19 vaccines in pregnant women from the safety surveillance registries, including " $v$-safe" and Vaccine Adverse Event Reporting System (VAERS). Their analysis included 35,691 pregnant v-safe participants. They reported injection-site pain, fatigue, headache, and myalgia as the most frequent local and systemic reactions after vaccination, which were more frequent after the second dose. The participant-measured temperature at or above $38{ }^{\circ} \mathrm{C}$ was reported by less than $1 \%$ of the participants on day one after dose one and by $8.0 \%$ after dose 2 for both vaccines. They commented that these patterns, including higher reporting of reactogenicity after dose 2, were similar to patterns observed among non-pregnant women. Pregnant women did not report having severe reactions more frequently than non-pregnant women, except for nausea and vomiting, which were reported slightly more frequently only after dose 2. 
Small numbers of pregnant people were inadvertently enrolled during vaccine clinical trials of Pfizer/BioNTech (23, including 11 in the vaccine arm), Moderna (13, including six in the vaccine arm), and Janssen vaccine (8, including 4 in the vaccine arm) $[61,83,94,95]$. They only reported unsolicited data on adverse events related to pregnancy, including miscarriage. In Pfizer/BioNTech $(1 / 12 ; 8 \%)$ and Moderna vaccine trials $(1 / 7 ; 14 \%)$ reported miscarriage only in the placebo group. In the Janssen vaccine trial, reported adverse events during pregnancy included spontaneous abortion ( 1 vaccine, 0 placebo), incomplete abortion ( 0 vaccine, 1 placebo), elective abortion ( 0 vaccine, 2 placebo), and ectopic pregnancy (1 vaccine, 0 placebo). The results are summarized in Table 2.

Table 2. Accidental pregnancies reported in COVID-19 vaccine trials.

\begin{tabular}{ccccccc}
\hline \multirow{2}{*}{ Vaccine Type } & \multicolumn{3}{c}{ Control/Placebo Group } & \multicolumn{3}{c}{ Vaccine Group } \\
\cline { 2 - 7 } & Participants & Pregnancies & Miscarriage (rate) & Participants & Pregnancies & Miscarriage (Rate) \\
\hline Pfizer/BioNTech & 18,846 & 12 & $1(8 \%)$ & 18,860 & 11 & 0 \\
\hline Moderna & 15,170 & 7 & $1(14 \%)$ & 15,181 & 6 & 0 \\
\hline Janssen & 21,888 & 4 & $1(25 \%)$ & 21,895 & 4 & $12 \%$ \\
\hline AstraZeneca & 5,829 & 9 & $3(33 \%)$ & 5,807 & & $2(17 \%)$ \\
\hline
\end{tabular}

\section{COVID-19 Vaccine Hesitancy}

Despite tremendous progress in vaccine development and administration, the current acceptance level of the COVID-19 vaccine remains inadequate to meet the requirements for developing herd immunity. The herd immunity threshold depends on the basic reproduction number of the disease. Assuming a basic reproductive number of 4 , the community immunity level needs to reach at least 75\% to stop the COVID-19 pandemic [96]. WHO has categorized vaccine hesitancy as one of the top ten threats to global health, even prior to the COVID-19 pandemic $[97,98]$. Therefore, it is important to understand and address the reason for vaccine hesitancy.

Skjefte et al. collected data from 17,871 respondents from 16 countries through an online survey between October 28 and November 18, 2020, assuming a hypothetical 90\% COVID-19 vaccine efficacy. Only 52.0\% of pregnant women $(n=2747 / 5282)$ and $73.4 \%$ of non-pregnant women $(n=9214 / 12,562)$ indicated an intention to receive the vaccine [98]. They noticed the top three reasons given by pregnant women to decline COVID-19 vaccination during pregnancy, even if the vaccine were safe and free, were: (i) that they did not want to expose their developing baby to any possible harmful side effects $(65.9 \%)$, (ii) were concerned that approval of the vaccine would be rushed for political reasons $(44.9 \%)$, and (iii) would like to see more safety and effectiveness data among pregnant women (48.8\%).

Vaccine hesitancy is a complex, multifaceted problem with significant variability based on region, race, ethnicity, pregnancy, education level, employment status, social and geopolitical influence [99]. Various steps, including rebuilding public vaccine confidence by uniform, consistent, transparent, and effective communication from policymakers, media, and health care providers, and effective community engagement are important to improve vaccine acceptance [98-100].

\section{Impact of COVID-19 Vaccine on Fetuses and Breastfeeding Infants}

Vaccination during pregnancy is known to provide protection to mother and infant from infectious agents including, e.g., influenza and pertussis. Various expert panels suggest that COVID-19 vaccine based on mRNA nanoparticle and adenovirus vector do not possess any significant risk to the fetus or breastfeeding infant [7,10-12,101-103], although there is no direct data on whether intact vaccine particles cross the placenta and enter fetal cells. However, studies done on other lipid nanoparticle-based vaccines suggest 
that they cannot cross the placenta $[86,104,105]$. Another small study including six lactating women showed no evidence of vaccine mRNA in breast milk samples collected within two days of vaccination [106].

From the analysis of the safety surveillance registries, including "v-safe" and Vaccine Adverse Event Reporting System (VAERS), Shimabukuro et al. reported pregnancy loss occurred in $13.9 \%$ of participants that had a completed pregnancy (i.e., live-born infant, spontaneous abortion, induced abortion, or stillbirth). They also note adverse neonatal outcomes of preterm birth (9.4\%) and small size for gestational age (3.2\%). No neonatal deaths were reported. Among 221 pregnancy-related adverse events reported to the VAERS, the most frequently reported event was spontaneous abortion (46 cases). Similar incidences of these pregnancy outcomes have been reported in studies involving pregnant women that were conducted before the COVID-19 pandemic [107-112].

Many experts have also suggested that vaccine-stimulated immunoglobulin A may pass through breast milk and provides additional protection to the infant against COVID$19[86,104-106,113,114]$. One study showed the presence of vaccine-derived IgA antibodies in breastmilk three to four weeks post-vaccination with the mRNA COVID-19 vaccines $(n=23)$ [106]. They also noted that IgA antibody titers in breastmilk were similar between participants receiving COVID-19 vaccination and COVID-19 infection. Another study, including 20 mother-infant pairs, demonstrated efficient transplacental transfer of anti-COVID-19 spike antibodies after antenatal vaccination with the Pfizer/BioNTech vaccine [113].

\section{Impact of COVID-19 Vaccine on Fertility}

For people in the reproductive age group or planning pregnancy, the effect of the COVID-19 vaccine is an important consideration. Fortunately, based on multiple reports, no evidence of an adverse effect on the fertility of women or men has been found [115-120].

It is interesting to note that COVID-19, in theory, may affect female fertility by damaging endometrial epithelial cells (affecting early embryo implantation), ovarian tissue, and granulosa cells (decreasing ovarian function and oocyte quality) by the release of proinflammatory cytokines [117-120]. However, no such clinical case has yet been reported.

According to the guidance issued by the British Fertility Society, there is "absolutely no evidence" that COVID-19 vaccines can affect the fertility of women or men [121]. They also stated that people undergoing fertility treatment (in vitro fertilization), frozen embryo transfer, egg freezing, ovulation induction, intrauterine insemination, donating eggs or sperms could receive the COVID-19 vaccine. However, they recommended separating the date of vaccination from treatment procedure by a few days to correctly attribute symptoms such as fever to vaccine or treatment procedure.

Orvieto et al. studied 36 couples undergoing IVF treatment 7-85 days after receiving the mRNA COVID-19 vaccine. They reported no in-between cycle differences in ovarian stimulation and embryological variables before and after receiving the mRNA COVID19 vaccine. They also noted that the mRNA COVID-19 vaccine did not affect patients' performance or ovarian reserve in their immediate subsequent IVF cycle.

\section{Recommendations for Health Care Providers}

The paucity of data describing COVID-19 vaccine safety, immunogenicity, and efficacy in pregnant and breastfeeding women has made the decision for vaccination a challenging one for many. However, multiple professional societies have offered recommendations to assist physicians and pregnant and breastfeeding women in making such decisions [104].

Health care providers should use a framework to support shared decision-making, providing evidence-based information and allowing the individual to weigh the risk and benefits of vaccination to make a well-informed decision. Health care providers should also try to identify the challenges during inpatient counseling and provide evidence-based and practical guidance addressing those challenges. For example, for vaccine hesitancy, 
physicians should ask patients to express their hesitation and reasons for it and respectfully address them.

The CDC's ACIP, ACOG, Society for Maternal-Fetal Medicine (SMFM), and Academy of Breastfeeding Medicine (ABM) recommend that all pregnant and breastfeeding people may choose to be vaccinated and that a discussion with their physician might assist them in making an informed decision $[85,101,102,104,108]$. Guidelines by various professional committees are summarized in Table 3.

Table 3. Guidelines by various professional committees for COVID vaccination in pregnant and lactating women.

\begin{tabular}{cc}
\hline Pregnant and Considering Pregnancy & Breastfeeding \\
\hline Advisory Committee on Immunization Practices (ACIP)
\end{tabular}

a. People who are pregnant and part of a group recommended to receive COVID-19 vaccination, such as health care personnel, may choose to be vaccinated

b. A conversation with a clinician may be helpful but is not required prior to vaccination a. No data on the safety of COVID-19 vaccines in lactating mothers or on the effects of mRNA vaccines on the breastfed infant

b. Individuals who meet criteria for vaccination based on ACIP-recommended priority group, may choose to be vaccinated

c. People who are trying to become pregnant do not need to avoid pregnancy after receiving an mRNA COVID-19 vaccine

American College of Obstetricians and Gynecologists (ACOG)

a. COVID-19 vaccines should not be withheld from pregnant individuals who meet criteria for vaccination based on ACIP-recommended priority groups a. COVID-19 vaccines should not be withheld from breastfeeding individuals who meet criteria for vaccination based on ACIP-recommended priority groups b. While a conversation with a clinician may be helpful, it should not be required prior to vaccination b. Theoretical risks of vaccinating lactating people do not outweigh the potential benefits of the vaccine

c. Pregnancy testing is not a requirement prior to receiving the COVID-19 vaccine

\section{Society for Maternal-Fetal Medicine (SMFM)}

a. Discuss potential benefits and unknown risks with their clinicians regarding receipt of vaccine

b. Individual decision-making needs to balance theoretical risks with risks associated with delayed vaccination and possible maternal SARS-CoV-2 infection

c. Counseling should also include the theoretical risk of harm to the fetus a. Vaccination recommended for lactating women

b. Counseling should balance lack of data on vaccine safety and a person's individual risk for infection and severe disease

c. Theoretical risks of vaccinating lactating people do not outweigh the potential benefits of the vaccine 
Table 3. Cont.

\begin{tabular}{lll}
\hline Pregnant and Considering Pregnancy & Breastfeeding \\
\hline Academy of Breastfeeding Medicine (ABM) & $\begin{array}{l}\text { Does not recommend cessation of breastfeeding for } \\
\text { individuals who are vaccinated against COVID-19 }\end{array}$ \\
\hline- & b. & $\begin{array}{l}\text { Discuss potential benefits and unknown risks with their } \\
\text { clinicians regarding receipt of vaccine }\end{array}$ \\
\hline c. & $\begin{array}{l}\text { While there is a little plausible risk for the child, there is a } \\
\text { biologically plausible benefit }\end{array}$ \\
\hline $\begin{array}{l}\text { Insufficient available data on COVID-19 } \\
\text { vaccine-associated risks in pregnancy }\end{array}$ & a. & $\begin{array}{l}\text { Insufficient available data on the effect of COVID-19 } \\
\text { vaccine- on the breastfed infant or on milk } \\
\text { production/excretion }\end{array}$ \\
\hline
\end{tabular}

\section{Special Considerations}

The CDC recommends that individuals with a severe and immediate allergic reaction to a previous dose of an mRNA COVID-19 vaccine, its components, or to polysorbate should not receive mRNA COVID-19 vaccination unless they have been evaluated by an allergist-immunologist, and it has been established that the individual can safely receive the vaccine.

Rare, albeit potentially life-threatening, cases of thrombosis have been reported after the administration of the Janssen vaccine. Pregnancy is a risk factor for thrombosis; therefore, pregnant women should be made aware of the increased risk for thrombosis with the Janssen vaccine. However, based on available data (15 cases after 7.98 million doses), the CDC recommends that the vaccine can still be given during pregnancy, as it continues to collect more clinical data $[48,122,123]$.

\section{Limitations}

There are limitations to this review. Our review only included data from FDA and WHO-approved COVID-19 vaccines. Several other potential COVID-19 vaccines remain under investigation. Furthermore, due to heterogeneity in population, vaccine research guidelines, and regulations among various countries, the head-to-head comparison of various other COVID-19 vaccines remains beyond the scope of this article. The literature search for this review included English-language articles only.

\section{Conclusions}

COVID-19 vaccination is the most promising means of controlling the spread of the COVID-19 global pandemic. It is important to safeguard our vulnerable population of pregnant and lactating women while also prioritizing their involvement in clinical trials for vaccine and anti-viral therapies and vaccine administration. Health care providers need to keep up to date with the new information to provide evidence-based information and effective counseling to pregnant and lactating women.

Author Contributions: Conceptualization, S.P., A.B.S. and R.S.; data curation, I.G.; writing-original draft preparation, I.G.; writing-review and editing, R.S., A.B.S. and S.P.; supervision, S.P. All authors have read and agreed to the published version of the manuscript.

Funding: This research received no external funding.

Institutional Review Board Statement: Not applicable.

Informed Consent Statement: Not applicable. 
Data Availability Statement: Not applicable.

Conflicts of Interest: The authors declare no conflict of interest.

\section{References}

1. WHO. WHO Coronavirus (COVID-19) Dashboard. Available online: https:/ / covid19.who.int (accessed on 5 June 2021).

2. Bank, W. COVID-19 to Add as Many as 150 Million Extreme Poor by 2021 World Bank. Available online: https://www. worldbank.org/en/news/press-release/2020/10/07/ covid-19-to-add-as-many-as-150-million-extreme-poor-by-2021 (accessed on 5 June 2021).

3. Pfizer. Pfizer and BioNTech Announce Vaccine Candidate Against COVID-19 Achieved Success in First Interim Analysis from Phase 3 Study. Available online: https://investors.pfizer.com/investor-news/press-release-details/2020/Pfizer-and-BioNTechAnnounce-Vaccine-Candidate-Against-COVID-19-Achieved-Success-in-First-Interim-Analysis-from-Phase-3-Study/default. aspx (accessed on 5 June 2021).

4. Moderna. Moderna Announces Primary Efficacy Analysis in Phase 3 COVE Study for its COVID-19 Vaccine Candidate and Filing Today with U.S. FDA for Emergency Use Authorization. Available online: https:/ / investors.modernatx.com/news-releases/ news-release-details / moderna-announces-primary-efficacy-analysis-phase-3-cove-study (accessed on 5 June 2021).

5. Zimmer, C.C.J.; Wee, S. Coronavirus Vaccine Tracker. Available online: https://www.nytimes.com/interactive/2020/science/ coronavirus-vaccine-tracker.html (accessed on 5 June 2021).

6. American College of Obstetricians \& Gynecologists. Vaccinating Pregnant and Lactating Patients against COVID-19. 2020. Available online: https://www.acog.org/en/clinical/clinical-guidance/practice-advisory/articles/2020/12/vaccinating-Pregnantand-Lactating-Patients-Against-COVID-19 (accessed on 5 June 2021).

7. Society for Maternal Fetal Medicine. SARS-Co-V-2 Vaccination in Pregnancy. Available online: https://s3.amazonaws.com/cdn. smfm.org/media/2591/SMFM_Vaccine_Statement_12-1-20 (accessed on 5 June 2021).

8. Academy of Breastfeeding Medicine Considerations for COVID-19 Vaccination in Lactation. Available online: https://abm. memberclicks.net/abm-statement-considerationsfor-covid-19-vaccination-in-lactation (accessed on 5 June 2021).

9. Centers for Disease Control and Prevention. COVID-19 (Coronavirus Disease): People with Certain Medical Conditions. Available online: https:/ / www.cdc.gov/coronavirus/2019-ncov/needextra-precautions/people-with-medical-conditions.html (accessed on 5 June 2021).

10. Royal College of Obstetricians \& Gynaecologists. Updated Advice on COVID-19 Vaccination in Pregnancy and Women Who Are Breastfeeding. Available online: https://www.rcog.org.uk/en/news/updated-advice-on-covid-19-vaccination-in-pregnancyand-women-whoare-breastfeeding/ (accessed on 5 June 2021).

11. Advisory Committee on Immunization Practices. ACIP Recommendations. Available online: https://www.cdc.gov/vaccines/ acip/recommendations.html (accessed on 5 June 2021).

12. Dooling, K.; Marin, M.; Wallace, M.; McClung, N.; Chamberland, M.; Lee, G.M.; Talbot, H.K.; Romero, J.R.; Bell, B.P.; Oliver, S.E. The Advisory Committee on Immunization Practices' Updated Interim Recommendation for Allocation of COVID-19 Vaccine-United States, December 2020. MMWR Morb. Mortal. Wkly. Rep. 2021, 69, 1657-1660. [CrossRef] [PubMed]

13. Zambrano, L.D.; Ellington, S.; Strid, P.; Galang, R.R.; Oduyebo, T.; Tong, V.T.; Woodworth, K.R.; Nahabedian, J.F., 3rd; AzzizBaumgartner, E.; Gilboa, S.M.; et al. Update: Characteristics of Symptomatic Women of Reproductive Age with LaboratoryConfirmed SARS-CoV-2 Infection by Pregnancy Status-United States, January 22-October 3, 2020. MMWR Morb. Mortal. Wkly. Rep. 2020, 69, 1641-1647. [CrossRef] [PubMed]

14. Allotey, J.; Stallings, E.; Bonet, M.; Yap, M.; Chatterjee, S.; Kew, T.; Debenham, L.; Llavall, A.C.; Dixit, A.; Zhou, D.; et al. Clinical manifestations, risk factors, and maternal and perinatal outcomes of coronavirus disease 2019 in pregnancy: Living systematic review and meta-analysis. BMJ 2020, 370, m3320. [CrossRef] [PubMed]

15. Galang, R.R.; Newton, S.M.; Woodworth, K.R.; Griffin, I.; Oduyebo, T.; Sancken, C.L.; Olsen, E.O.; Aveni, K.; Wingate, H.; Shephard, H.; et al. Risk factors for illness severity among pregnant women with confirmed SARS-CoV-2 infection-Surveillance for Emerging Threats to Mothers and Babies Network, 22 state, local, and territorial health departments, March 29, 2020-March 5, 2021. Clin. Infect. Dis. 2021. [CrossRef] [PubMed]

16. Mullins, E.; Hudak, M.L.; Banerjee, J.; Getzlaff, T.; Townson, J.; Barnette, K.; Playle, R.; Perry, A.; Bourne, T.; Lees, C.C.; et al. Pregnancy and neonatal outcomes of COVID-19: Coreporting of common outcomes from PAN-COVID and AAP-SONPM registries. Ultrasound Obs. Gynecol. 2021, 57, 573-581. [CrossRef] [PubMed]

17. Schwartz, D.A. An Analysis of 38 Pregnant Women With COVID-19, Their Newborn Infants, and Maternal-Fetal Transmission of SARS-CoV-2: Maternal Coronavirus Infections and Pregnancy Outcomes. Arch. Pathol. Lab. Med. 2020, 144, 799-805. [CrossRef] [PubMed]

18. Flaherman, V.J.; Afshar, Y.; Boscardin, J.; Keller, R.L.; Mardy, A.; Prahl, M.K.; Phillips, C.; Asiodu, I.V.; Berghella, W.V.; Chambers, B.D.; et al. Infant Outcomes Following Maternal Infection with SARS-CoV-2: First Report from the PRIORITY Study. Clin. Infect. Dis. 2020, 2, 1-4. [CrossRef]

19. Kotlyar, A.M.; Grechukhina, O.; Chen, A.; Popkhadze, S.; Grimshaw, A.; Tal, O.; Taylor, H.S.; Tal, R. Vertical transmission of coronavirus disease 2019: A systematic review and meta-analysis. Am. J. Obstet. Gynecol. 2021, 224, 35-53. [CrossRef] [PubMed]

20. Leung, C. Clinical characteristics of COVID-19 in children: Are they similar to those of SARS? Pediatr. Pulmonol. 2020, 55, 1592-1597. [CrossRef] 
21. Edlow, A.G.; Li, J.Z.; Collier, A.Y.; Atyeo, C.; James, K.E.; Boatin, A.A.; Gray, K.J.; Bordt, E.A.; Shook, L.L.; Yonker, L.M.; et al. Assessment of Maternal and Neonatal SARS-CoV-2 Viral Load, Transplacental Antibody Transfer, and Placental Pathology in Pregnancies During the COVID-19 Pandemic. JAMA Netw. Open 2020, 3, e2030455. [CrossRef]

22. Dumitriu, D.; Emeruwa, U.N.; Hanft, E.; Liao, G.V.; Ludwig, E.; Walzer, L.; Arditi, B.; Saslaw, M.; Andrikopoulou, M.; Scripps, T.; et al. Outcomes of Neonates Born to Mothers With Severe Acute Respiratory Syndrome Coronavirus 2 Infection at a Large Medical Center in New York City. JAMA Pediatr. 2021, 175, 157-167. [CrossRef] [PubMed]

23. Prabhu, M.; Cagino, K.; Matthews, K.C.; Friedlander, R.L.; Glynn, S.M.; Kubiak, J.M.; Yang, Y.J.; Zhao, Z.; Baergen, R.N.; DiPace, J.I.; et al. Pregnancy and postpartum outcomes in a universally tested population for SARS-CoV-2 in New York City: A prospective cohort study. BJOG 2020, 127, 1548-1556. [CrossRef] [PubMed]

24. Gross, R.; Conzelmann, C.; Muller, J.A.; Stenger, S.; Steinhart, K.; Kirchhoff, F.; Munch, J. Detection of SARS-CoV-2 in human breastmilk. Lancet 2020, 395, 1757-1758. [CrossRef]

25. Chambers, C.; Krogstad, P.; Bertrand, K.; Contreras, D.; Tobin, N.H.; Bode, L.; Aldrovandi, G. Evaluation for SARS-CoV-2 in Breast Milk From 18 Infected Women. JAMA 2020, 324, 1347-1348. [CrossRef] [PubMed]

26. Centeno-Tablante, E.; Medina-Rivera, M.; Finkelstein, J.L.; Rayco-Solon, P.; Garcia-Casal, M.N.; Rogers, L.; Ghezzi-Kopel, K.; Ridwan, P.; Pena-Rosas, J.P.; Mehta, S. Transmission of SARS-CoV-2 through breast milk and breastfeeding: A living systematic review. Ann. N. Y. Acad. Sci. 2021, 1484, 32-54. [CrossRef]

27. Centers for Disease Control and Prevention. COVID-19 Vaccines: Interim Clinical Considerations for Use of COVID-19 Vaccines Currently Authorized in the United States. Available online: https://www.cdc.gov/vaccines/covid-19/clinical-considerations/ covid-19-vaccines-us.html (accessed on 5 June 2021).

28. American Academy of Pediatrics. COVID-19 Vaccines in Children and Adolescents. Available online: https://pediatrics. aappublications.org/content/pediatrics/early/2021/05/11/peds.2021-052336.full.pdf (accessed on 5 June 2021).

29. Times, T.N.Y. Coronavirus Vaccine Tracker. Available online: https://www.nytimes.com/interactive/2020/science/coronavirusvaccine-tracker.html (accessed on 5 June 2021).

30. U.S.F.D.A. Emergency Use Authorization. Available online: https://www.fda.gov/emergency-preparedness-and-response/ mcm-legal-regulatory-and-policy-framework/emergency-use-authorization (accessed on 5 June 2021).

31. U.S.F.D.A. Emergency Use Authorization for Vaccines to Prevent COVID-19. Available online: https://www.fda.gov/ regulatory-information/search-fda-guidance-documents/emergency-use-authorization-vaccines-prevent-covid-19 (accessed on 5 June 2021).

32. Kaur, S.P.; Gupta, V. COVID-19 Vaccine: A comprehensive status report. Virus Res. 2020, 288, 198114. [CrossRef]

33. Huang, Y.; Yang, C.; Xu, X.F.; Xu, W.; Liu, S.W. Structural and functional properties of SARS-CoV-2 spike protein: Potential antivirus drug development for COVID-19. Acta Pharmacol. Sin. 2020, 41, 1141-1149. [CrossRef]

34. Xia, S.; Zhu, Y.; Liu, M.; Lan, Q.; Xu, W.; Wu, Y.; Ying, T.; Liu, S.; Shi, Z.; Jiang, S.; et al. Fusion mechanism of 2019-nCoV and fusion inhibitors targeting HR1 domain in spike protein. Cell. Mol. Immunol. 2020, 17, 765-767. [CrossRef]

35. Padron-Regalado, E. Vaccines for SARS-CoV-2: Lessons from Other Coronavirus Strains. Infect. Dis. Ther. 2020, 9, 1-20. [CrossRef]

36. Pallesen, J.; Wang, N.; Corbett, K.S.; Wrapp, D.; Kirchdoerfer, R.N.; Turner, H.L.; Cottrell, C.A.; Becker, M.M.; Wang, L.; Shi, W.; et al. Immunogenicity and structures of a rationally designed prefusion MERS-CoV spike antigen. Proc. Natl. Acad. Sci. USA 2017, 114, E7348-E7357. [CrossRef]

37. Dai, L.; Gao, G.F. Viral targets for vaccines against COVID-19. Nat. Rev. Immunol. 2021, 21, 73-82. [CrossRef]

38. Polack, F.P.; Thomas, S.J.; Kitchin, N.; Absalon, J.; Gurtman, A.; Lockhart, S.; Perez, J.L.; Perez Marc, G.; Moreira, E.D.; Zerbini, C.; et al. Safety and Efficacy of the BNT162b2 mRNA Covid-19 Vaccine. N. Engl. J. Med. 2020, 383, 2603-2615. [CrossRef]

39. Baden, L.R.; El Sahly, H.M.; Essink, B.; Kotloff, K.; Frey, S.; Novak, R.; Diemert, D.; Spector, S.A.; Rouphael, N.; Creech, C.B.; et al. Efficacy and Safety of the mRNA-1273 SARS-CoV-2 Vaccine. N. Engl. J. Med. 2021, 384, 403-416. [CrossRef]

40. Walsh, E.E.; Frenck, R.; Falsey, A.R.; Kitchin, N.; Absalon, J.; Gurtman, A.; Lockhart, S.; Neuzil, K.; Mulligan, M.J.; Bailey, R.; et al. RNA-Based COVID-19 Vaccine BNT162b2 Selected for a Pivotal Efficacy Study. medRxiv 2020. [CrossRef]

41. F.D.A. Vaccines and Related Biological Products Advisory Committee December 10, 2020 Meeting Announcement. Available online: https:/ / www.fda.gov/advisory-committees/advisory-committee-calendar/vaccines-and-related-biological-productsadvisory-committee-december-10-2020-meeting-announcement (accessed on 5 June 2021).

42. F.D.A. Vaccines and Related Biological Products Advisory Committee Meeting Presentation. Available online: https://www.fda. gov/media/144452/download (accessed on 5 June 2021).

43. F.D.A. Vaccines and Related Biological Products Advisory Committee Meeting December 10, 2020. Available online: https: / / www.fda.gov/media/144245/download (accessed on 5 June 2021).

44. CDC. Interim Estimates of Vaccine Effectiveness of BNT162b2 and mRNA-1273 COVID-19 Vaccines in Preventing SARS-CoV-2 Infection Among Health Care Personnel, First Responders, and Other Essential and Frontline Workers-Eight U.S. Locations, December 2020-March 2021. Morb. Mortal. Wkly. Rep. 2021, 70, 495.

45. FDA. Janssen Biotech. Available online: https://www.fda.gov/media/146303/download (accessed on 5 June 2021 ).

46. CDC. Thrombosis with Thrombocytopenia Syndrome (TTS) Following Janssen COVID-19 Vaccine. Available online: https: / / www.cdc.gov/vaccines/acip/meetings/downloads/slides-2021-04-23/03-COVID-Shimabukuro-508.pdf (accessed on 5 June 2021). 
47. Medicine, J.H. Thrombosis. Available online: https://www.hopkinsmedicine.org/health/conditions-and-diseases/thrombosis (accessed on 5 June 2021).

48. CDC. J\&J/Janssen Update. Available online: https://www.cdc.gov/coronavirus/2019-ncov/vaccines/safety/JJUpdate.html (accessed on 5 June 2021).

49. Novavax. Novavax Confirms High Levels of Efficacy against Original and Variant COVID-19 Strains in United Kingdom and South Africa Trials. Available online: https://ir.novavax.com/news-releases/news-release-details/novavax-confirms-highlevels-efficacy-against-original-and-0 (accessed on 5 June 2021).

50. Bianchi, D.W.; Kaeser, L.; Cernich, A.N. Involving Pregnant Individuals in Clinical Research on COVID-19 Vaccines. JAMA 2021, 325, 1041-1042. [CrossRef] [PubMed]

51. Riley, L.E.; Jamieson, D.J. Inclusion of Pregnant and Lactating Persons in COVID-19 Vaccination Efforts. Ann. Intern. Med. 2021, 174, 701-702. [CrossRef] [PubMed]

52. Beigi, R.H.; Krubiner, C.; Jamieson, D.J.; Lyerly, A.D.; Hughes, B.; Riley, L.; Faden, R.; Karron, R. The need for inclusion of pregnant women in COVID-19 vaccine trials. Vaccine 2021, 39, 868-870. [CrossRef]

53. Klein, S.L.; Creisher, P.S.; Burd, I. COVID-19 vaccine testing in pregnant females is necessary. J. Clin. Investg. 2021, 131. [CrossRef]

54. Spong, C.Y.; Bianchi, D.W. Improving Public Health Requires Inclusion of Underrepresented Populations in Research. JAMA 2018, 319, 337-338. [CrossRef] [PubMed]

55. Mullard, A. Flooded by the torrent: The COVID-19 drug pipeline. Lancet 2020, 395, 1245-1246. [CrossRef]

56. Malhotra, A.; Kumar, A.; Roehr, C.C.; den Boer, M.C. Inclusion of children and pregnant women in COVID-19 intervention trials Pediatr. Res. 2021, 89, 1063-1064. [CrossRef]

57. Dashraath, P.; Nielsen-Saines, K.; Madhi, S.A.; Baud, D. COVID-19 vaccines and neglected pregnancy. Lancet 2020, 396 , e22. [CrossRef]

58. FDA. Pregnant Women: Scientific and Ethical Considerations for Inclusion in Clinical Trial. Available online: https://www. fda.gov/regulatory-information/search-fda-guidance-documents / pregnant-women-scientific-and-ethical-considerationsinclusion-clinical-trials (accessed on 5 June 2021).

59. HHSTask Force on Research Specific to Pregnant Women and Lactating Women. Available online: https://www.nichd.nih.gov/ sites / default/files/2018-09/PRGLAC_Report.pdf (accessed on 5 June 2021).

60. F.D.A. Development and Licensure of Vaccines to Prevent COVID-19-Guidance for Industry. Available online: https://www.fda. gov/media/139638/download (accessed on 5 June 2021).

61. F.D.A. Vaccines and Related Biological Products Advisory Committee December 17, 2020 Meeting Announcement DECEMBER 17. 2020. Available online: https://www.fda.gov/advisory-committees/advisory-committee-calendar/vaccines-and-relatedbiological-products-advisory-committee-december-17-2020-meeting-announcement (accessed on 5 June 2021).

62. BioNTech. Pfizer and Biontech Commence Global Clinical Trial to Evaluate COVID-19 Vaccine in Pregnant Women. Available online: https:/ / www.pfizer.com/news/press-release/press-release-detail/pfizer-and-biontech-commence-global-clinical-trialevaluate (accessed on 5 June 2021).

63. Moderna. Frequently Asked Questions: What Is Known about the Safety of the Vaccine for Special Populations (Children, Pregnant Women, Elderly People)? Available online: https:/ /www.modernatx.com/covid19vaccine-eua/providers/faq\#patientvaccination (accessed on 5 June 2021).

64. Rubin, R. Pregnant People's Paradox-Excluded From Vaccine Trials Despite Having a Higher Risk of COVID-19 Complications. JAMA 2021, 325, 1027-1028. [CrossRef]

65. National Center for Immunization \& Respiratory Diseases. COVID-19 Vaccine Safety Update Advisory Committee on Immunization Practices (ACIP) January 27. 2021. Available online: https:/ /www.cdc.gov/vaccines/acip/meetings/downloads/slides-20 21-01/06-COVID-Shimabukuro.pdf (accessed on 5 June 2021).

66. COVID-19: The Green Book, Chapter 14a. Available online: https://assets.publishing.service.gov.uk/government/uploads/ system/uploads/attachment_data/file/984310/Greenbook_chapter_14a_7May2021.pdf (accessed on 5 June 2021).

67. Agency, E.M. Paediatric Investigation Plans. Available online: https://www.ema.europa.eu/en/human-regulatory/researchdevelopment/paediatric-medicines/paediatric-investigation-plans (accessed on 5 June 2021).

68. Modi, N.; Ayres-de-Campos, D.; Bancalari, E.; Benders, M.; Briana, D.; Di Renzo, G.C.; Fonseca, E.B.; Hod, M.; Poon, L.; Cortes, M.S.; et al. Equity in coronavirus disease 2019 vaccine development and deployment. Am. J. Obstet. Gynecol. 2021, 224, $423-427$. [CrossRef]

69. Minkoff, H.; Ecker, J. Balancing risks: Making decisions for maternal treatment without data on fetal safety. Am. J. Obstet. Gynecol. 2021, 224, 479-483. [CrossRef]

70. Stafford, I.A.; Parchem, J.G.; Sibai, B.M. The coronavirus disease 2019 vaccine in pregnancy: Risks, benefits, and recommendations. Am. J. Obstet. Gynecol. 2021, 224, 484-495. [CrossRef] [PubMed]

71. Zipursky, J.S.; Greenberg, R.A.; Maxwell, C.; Bogler, T. Pregnancy, breastfeeding and the SARS-CoV-2 vaccine: An ethics-based framework for shared decision-making. CMAJ 2021, 193, E312-E314. [CrossRef]

72. McNeil, M.M.; Gee, J.; Weintraub, E.S.; Belongia, E.A.; Lee, G.M.; Glanz, J.M.; Nordin, J.D.; Klein, N.P.; Baxter, R.; Naleway, A.L.; et al. The Vaccine Safety Datalink: Successes and challenges monitoring vaccine safety. Vaccine 2014, 32, 5390-5398. [CrossRef] 
73. Naleway, A.L.; Gold, R.; Kurosky, S.; Riedlinger, K.; Henninger, M.L.; Nordin, J.D.; Kharbanda, E.O.; Irving, S.; Cheetham, T.C.; McCarthy, N.L. Identifying pregnancy episodes, outcomes, and mother-infant pairs in the Vaccine Safety Datalink. Vaccine 2013, 31, 2898-2903. [CrossRef] [PubMed]

74. Sejvar, J.J.; Kohl, K.S.; Gidudu, J.; Amato, A.; Bakshi, N.; Baxter, R.; Burwen, D.R.; Cornblath, D.R.; Cleerbout, J.; Edwards, K.M.; et al. Guillain-Barre syndrome and Fisher syndrome: Case definitions and guidelines for collection, analysis, and presentation of immunization safety data. Vaccine 2011, 29, 599-612. [CrossRef]

75. Wang, S.V.; Stefanini, K.; Lewis, E.; Newcomer, S.R.; Fireman, B.; Daley, M.F.; Glanz, J.M.; Duffy, J.; Weintraub, E.; Kulldorff, M. Determining Which of Several Simultaneously Administered Vaccines Increase Risk of an Adverse Event. Drug Saf. 2020, 43, 1057-1065. [CrossRef] [PubMed]

76. Glanz, J.M.; Newcomer, S.R.; Daley, M.F.; DeStefano, F.; Groom, H.C.; Jackson, M.L.; Lewin, B.J.; McCarthy, N.L.; McClure, D.L.; Narwaney, K.J.; et al. Association Between Estimated Cumulative Vaccine Antigen Exposure Through the First 23 Months of Life and Non-Vaccine-Targeted Infections From 24 Through 47 Months of Age. JAMA 2018, 319, 906-913. [CrossRef] [PubMed]

77. Li, R.; Stewart, B.; Rose, C. A Bayesian approach to sequential analysis in post-licensure vaccine safety surveillance. Pharm. Stat. 2020, 19, 291-302. [CrossRef]

78. Yu, W.; Zheng, C.; Xie, F.; Chen, W.; Mercado, C.; Sy, L.S.; Qian, L.; Glenn, S.; Tseng, H.F.; Lee, G.; et al. The use of natural language processing to identify vaccine-related anaphylaxis at five health care systems in the Vaccine Safety Datalink. Pharmacoepidemiol. Drug Saf. 2020, 29, 182-188. [CrossRef] [PubMed]

79. Dudley, M.Z.; Halsey, N.A.; Omer, S.B.; Orenstein, W.A.; O'Leary, S.T.; Limaye, R.J.; Salmon, D.A. The state of vaccine safety science: Systematic reviews of the evidence. Lancet Infect. Dis. 2020, 20, e80-e89. [CrossRef]

80. Kochhar, S. Communicating vaccine safety during the development and introduction of vaccines. Curr. Drug Saf. 2015, 10, 55-59. [CrossRef] [PubMed]

81. Fortner, K.B.; Nieuwoudt, C.; Reeder, C.F.; Swamy, G.K. Infections in Pregnancy and the Role of Vaccines. Obstet. Gynecol. Clin. N. Am. 2018, 45, 369-388. [CrossRef]

82. Jackson, L.A.; Anderson, E.J.; Rouphael, N.G.; Roberts, P.C.; Makhene, M.; Coler, R.N.; McCullough, M.P.; Chappell, J.D.; Denison, M.R.; Stevens, L.J.; et al. An mRNA Vaccine against SARS-CoV-2-Preliminary Report. N. Engl. J. Med. 2020, 383, $1920-1931$. [CrossRef] [PubMed]

83. FDA. Moderna COVID-19 Vaccine. Available online: https://www.fda.gov/emergency-preparedness-and-response/ coronavirus-disease-2019-covid-19/moderna-covid-19-vaccine (accessed on 5 June 2021).

84. CDC. The Advisory Committee on Immunization Practices' Interim Recommendation for Use of Moderna COVID-19 VaccineUnited States. December 2020. Available online: https:/ / www.cdc.gov/mmwr/volumes/69/wr/mm695152e1.htm (accessed on 5 June 2021).

85. CDC. Advisory Committee on Immunization Practices' Interim Recommendation for Use of Pfizer- BioNTech COVID-19 VaccineUnited States. December 2020. Available online: https://www.cdc.gov/mmwr/volumes/69/wr/mm6950e2.htm (accessed on 5 June 2021).

86. Craig, A.M.; Hughes, B.L.; Swamy, G.K. Coronavirus disease 2019 vaccines in pregnancy. Am. J. Obstet. Gynecol. MFM 2021, 3 , 100295. [CrossRef]

87. Maruggi, G.; Zhang, C.; Li, J.; Ulmer, J.B.; Yu, D. mRNA as a Transformative Technology for Vaccine Development to Control Infectious Diseases. Mol. Ther. 2019, 27, 757-772. [CrossRef] [PubMed]

88. Pardi, N.; Hogan, M.J.; Porter, F.W.; Weissman, D. mRNA vaccines-A new era in vaccinology. Nat. Rev. Drug Discov. 2018, 17, 261-279. [CrossRef]

89. Zhang, C.; Maruggi, G.; Shan, H.; Li, J. Advances in mRNA Vaccines for Infectious Diseases. Front. Immunol. 2019, 10, 594. [CrossRef] [PubMed]

90. Alberer, M.; Gnad-Vogt, U.; Hong, H.S.; Mehr, K.T.; Backert, L.; Finak, G.; Gottardo, R.; Bica, M.A.; Garofano, A.; Koch, S.D.; et al. Safety and immunogenicity of a mRNA rabies vaccine in healthy adults: An open-label, non-randomised, prospective, first-in-human phase 1 clinical trial. Lancet 2017, 390, 1511-1520. [CrossRef]

91. Feldman, R.A.; Fuhr, R.; Smolenov, I.; Ribeiro, A.M.; Panther, L.; Watson, M.; Senn, J.J.; Smith, M.; Almarsson, Ö.; Pujar, H.S.; et al. mRNA vaccines against H10N8 and H7N9 influenza viruses of pandemic potential are immunogenic and well tolerated in healthy adults in phase 1 randomized clinical trials. Vaccine 2019, 37, 3326-3334. [CrossRef]

92. Richner, J.M.; Himansu, S.; Dowd, K.A.; Butler, S.L.; Salazar, V.; Fox, J.M.; Julander, J.G.; Tang, W.W.; Shresta, S.; Pierson, T.C.; et al. Modified mRNA Vaccines Protect against Zika Virus Infection. Cell 2017, 168, 1114-1125. [CrossRef]

93. Gray, K.J.; Bordt, E.A.; Atyeo, C.; Deriso, E.; Akinwunmi, B.; Young, N.; Baez, A.M.; Shook, L.L.; Cvrk, D.; James, K.; et al. Coronavirus disease 2019 vaccine response in pregnant and lactating women: A cohort study. Am. J. Obstet. Gynecol. 2021. [CrossRef]

94. FDA. Vaccines and Related Biological Products Advisory Committee Meeting February 26, 2021: FDA Briefing Document, Janssen Ad26.COV2.S Vaccine for the Prevention of COVID-19. Available online: https://www.fda.gov/media/146217/download (accessed on 5 June 2021).

95. FDA. Vaccines and Related Biological Products Advisory Committee Meeting December 10, 2020: FDA Briefing Document, Pfizer-BioNTech COVID-19 Vaccine. Available online: https:/ / www.fda.gov/media/144245/download (accessed on 5 June 2021). 
96. Jaffe, E.; Goldfarb, I.T.; Lyerly, A.D. The Costs of Contradictory Messages About Live Vaccines in Pregnancy. Am. J. Public Health 2021, 111, 498-503. [CrossRef]

97. WHO. Report of the Sage Working Group on Vaccine Hesitancy. Available online: https://www.who.int/immunization/sage/ meetings/2014/october/1_Report_WORKING_GROUP_vaccine_hesitancy_final.pdf (accessed on 5 June 2021).

98. Skjefte, M.; Ngirbabul, M.; Akeju, O.; Escudero, D.; Hernandez-Diaz, S.; Wyszynski, D.F.; Wu, J.W. COVID-19 vaccine acceptance among pregnant women and mothers of young children: Results of a survey in 16 countries. Eur. J. Epidemiol. 2021, 36, 197-211. [CrossRef] [PubMed]

99. Ceulemans, M.; Foulon, V.; Panchaud, A.; Winterfeld, U.; Pomar, L.; Lambelet, V.; Cleary, B.; O'Shaughnessy, F.; Passier, A.; Richardson, J.L.; et al. Vaccine Willingness and Impact of the COVID-19 Pandemic on Women's Perinatal Experiences and Practices-A Multinational, Cross-Sectional Study Covering the First Wave of the Pandemic. Int. J. Environ. Res. Public Health 2021, 18, 3367. [CrossRef]

100. ClincalTrials.gov. International Registry of Coronavirus (COVID-19) Exposure in Pregnancy (IRCEP). Available online: https: / / clinicaltrials.gov/ct2/show / NCT04366986 (accessed on 5 June 2021).

101. Society for Maternal Fetal Medicine. Society for Maternal-Fetal Medicine (SMFM) Statement: SARS-CoV-2 Vaccination in Pregnancy. Available online: https://s3.amazonaws.com/cdn.smfm.org/media/2591/SMFM_Vaccine_Statement_12-1-20_(final) .pdf (accessed on 5 June 2021).

102. Academy of Breastfeeding Medicine. ABM STATEMENT-Considerations for COVID-19 Vaccination in Lactation. Available online: https:/ / www.bfmed.org/abm-statement-considerations-for-covid-19-vaccination-in-lactation (accessed on 5 June 2021).

103. CDC. Medical Conditions. Available online: https://www.cdc.gov/coronavirus/2019-ncov/need-extra-precautions/peoplewith-medical-conditions.html (accessed on 5 June 2021).

104. Rasmussen, S.A.; Kelley, C.F.; Horton, J.P.; Jamieson, D.J. Coronavirus Disease 2019 (COVID-19) Vaccines and Pregnancy: What Obstetricians Need to Know. Obstet. Gynecol. 2021, 137, 408-414. [CrossRef] [PubMed]

105. Refuerzo, J.S.; Alexander, J.F.; Leonard, F.; Leon, M.; Longo, M.; Godin, B. Liposomes: A nanoscale drug carrying system to prevent indomethacin passage to the fetus in a pregnant mouse model. Am. J. Obstet. Gynecol. 2015, 212, 508.e1-508.e7. [CrossRef] [PubMed]

106. Golan, Y.; Prahl, M.; Cassidy, A.; Lin, C.Y.; Ahituv, N.; Flaherman, V.J.; Gaw, S.L. COVID-19 mRNA vaccine is not detected in human milk. medRxiv 2021. [CrossRef]

107. Shimabukuro, T.T.; Kim, S.Y.; Myers, T.R.; Moro, P.L.; Oduyebo, T.; Panagiotakopoulos, L.; Marquez, P.L.; Olson, C.K.; Liu, R.; Chang, K.T.; et al. Preliminary Findings of mRNA Covid-19 Vaccine Safety in Pregnant Persons. N. Engl. J. Med. 2021, 384, 2273-2282. [CrossRef] [PubMed]

108. American College of Obstetricians and Gynecologists. ACOG Practice Bulletin No. 200: Early Pregnancy Loss. Obstet. Gynecol. 2018, 132, e197-e207. [CrossRef]

109. Practice Committee of the American Society for Reproductive Medicine. Evaluation and treatment of recurrent pregnancy loss: A committee opinion. Fertil. Steril. 2012, 98, 1103-1111. [CrossRef]

110. Panagiotakopoulos, L.; McCarthy, N.L.; Tepper, N.K.; Kharbanda, E.O.; Lipkind, H.S.; Vazquez-Benitez, G.; McClure, D.L.; Greenberg, V.; Getahun, D.; Glanz, J.M.; et al. Evaluating the Association of Stillbirths After Maternal Vaccination in the Vaccine Safety Datalink. Obstet. Gynecol. 2020, 136, 1086-1094. [CrossRef]

111. Ferre, C.; Callaghan, W.; Olson, C.; Sharma, A.; Barfield, W. Effects of Maternal Age and Age-Specific Preterm Birth Rates on Overall Preterm Birth Rates-United States, 2007 and 2014. MMWR Morb. Mortal. Wkly. Rep. 2016, 65, 1181-1184. [CrossRef]

112. Boghossian, N.S.; Geraci, M.; Edwards, E.M.; Horbar, J.D. Morbidity and Mortality in Small for Gestational Age Infants at 22 to 29 Weeks' Gestation. Pediatrics 2018, 141. [CrossRef]

113. Rottenstreich, A.; Zarbiv, G.; Oiknine-Djian, E.; Zigron, R.; Wolf, D.G.; Porat, S. Efficient maternofetal transplacental transfer of anti- SARS-CoV-2 spike antibodies after antenatal SARS-CoV-2 BNT162b2 mRNA vaccination. Clin. Infect. Dis. 2021. [CrossRef]

114. Gov.UK. The safety of COVID-19 Vaccines When Given in Pregnancy. Available online: https://www.gov.uk/government/ publications / safety-of-covid-19-vaccines-when-given-in-pregnancy/the-safety-of-covid-19-vaccines-when-given-inpregnancy (accessed on 5 June 2021).

115. Gleicher, N.; Barad, D. Unexplained infertility: Does it really exist? Hum. Reprod. 2006, 21, 1951-1955. [CrossRef]

116. Orvieto, R.; Noach-Hirsh, M.; Segev-Zahav, A.; Haas, J.; Nahum, R.; Aizer, A. Does mRNA SARS-CoV-2 vaccine influence patients' performance during IVF-ET cycle? Reprod. Biol. Endocrinol. 2021, 19, 69. [CrossRef]

117. Reis, F.M.; Bouissou, D.R.; Pereira, V.M.; Camargos, A.F.; dos Reis, A.M.; Santos, R.A. Angiotensin-(1-7), its receptor Mas, and the angiotensin-converting enzyme type 2 are expressed in the human ovary. Fertil. Steril. 2011, 95, 176-181. [CrossRef] [PubMed]

118. Vaz-Silva, J.; Carneiro, M.M.; Ferreira, M.C.; Pinheiro, S.V.; Silva, D.A.; Silva-Filho, A.L.; Witz, C.A.; Reis, A.M.; Santos, R.A.; Reis, F.M. The vasoactive peptide angiotensin-(1-7), its receptor Mas and the angiotensin-converting enzyme type 2 are expressed in the human endometrium. Reprod. Sci. 2009, 16, 247-256. [CrossRef] [PubMed]

119. Pereira, V.M.; Reis, F.M.; Santos, R.A.; Cassali, G.D.; Santos, S.H.; Honorato-Sampaio, K.; dos Reis, A.M. Gonadotropin stimulation increases the expression of angiotensin-(1-7) and MAS receptor in the rat ovary. Reprod. Sci. 2009, 16, 1165-1174. [CrossRef]

120. Coperchini, F.; Chiovato, L.; Croce, L.; Magri, F.; Rotondi, M. The cytokine storm in COVID-19: An overview of the involvement of the chemokine/chemokine-receptor system. Cytokine Growth Factor Rev. 2020, 53, 25-32. [CrossRef] [PubMed] 
121. British Fertility Society and Association of Reproductive and Clinical Scientists. BFS \& ARCS Covid-19 Vaccines \& Fertility. Available online: https://www.britishfertilitysociety.org.uk/2021/02/09/bfs-arcs-covid-19-vaccines-fertility/ (accessed on 5 June 2021).

122. Oldenburg, J.; Klamroth, R.; Langer, F.; Albisetti, M.; von Auer, C.; Ay, C.; Korte, W.; Scharf, R.E.; Potzsch, B.; Greinacher, A Diagnosis and Management of Vaccine-Related Thrombosis following AstraZeneca COVID-19 Vaccination: Guidance Statement from the GTH. Hamostaseologie 2021, 41, 184-189. [CrossRef] [PubMed]

123. James, A.H. Thrombosis in pregnancy and maternal outcomes. Birth Defects Res. C Embryo Today 2015, 105, 159-166. [CrossRef] [PubMed] 